\title{
Evaluation of nitrogen fertiliser in a beef production system
}

\section{S.T. Morris' and A.F. McRae ${ }^{2}$}

'Department of Animal Science
Department of Agricultural and Horticultural
Systems Management, Massey University

ABSTRACT This paper reports and discusses the results of 4 years of trials (1985-1988) involving 2 farmlets, one receiving 3 nitrogen applications $(50 \mathrm{~kg}$ /ha) in autumn, winter and spring $(+\mathrm{N})$ and one receiving no $\mathrm{N}$ fertiliser (-N). Stocking rags were 3.3 animals/ha on $-\mathrm{N}$ farmlet and 4.3 animals/ha on the $+\mathrm{N}$ farmlet for the first 3 years, with the objective being to utilise the extra N-boosted grass with extra animals/ha but not to sacrifice individual animal performance. In the fourth year the stocking rates were kept the same on each farmlet (3.3 animals/ha) in an endeavour to utilise the extra grass grown on the $+\mathrm{N}$ farmlet by way of increased per head performance. In 2 of the 3 years (1985 and 1987) where the $+\mathbf{N}$ farmlet supported the higher stocking rate, liveweight gain (LWG) did not differ between animals. In 1986 the extra animals on the -l-N farmlet had a lower LWG, whereas in 1988 the LWGs were similar for the 2 farmlets stocked at the same rate. The apparent DM responses (kg DM/kg N applied) ranged from 2 to 12 . The rates of $\mathrm{N}$ fertiliser used in this trial do not appear to result in economic increases in pasture production for the beef production system reported here. Nitrogen fertiliser did not reduce the clover content of pastures rotationally grazed by beef cattle.

Keywords beef production, nitrogen fertiliser, pasture composition, livewieght gain, economics.

\section{INTRODUCTION}

Bull beef production systems, like the one implemented at Massey University's Tuapaka Farm, where animals reach carcass weights of 240 $\mathrm{kg}$ at 15-20 months of age (McRae 1988), are well accepted by commercial beef farmers. While some scope may exist for changing stocking rates and per head performance levels, further increases in production and profit from these systems appear to depend on increases in the annual available feed supply. Regular application of nitrogen (N) fertiliser is one strategy which may increase annual feed supply. In the past, New Zealand pastures have relied on the symbiotic $\mathrm{N}$ fixation by white clover in particular. Little $\mathrm{N}$ fertiliser has been used.
It is well established that plants require more $\mathrm{N}$ than any other nutrients derived from soil (Syers 1982). Recent research indicates the amount of $\mathrm{N}$ fixed in grazed swards is much less than first thought (Hoglund et al. 1979). Field \& Ball ( 198 1) reported that the more intensively utilised dairy farms may be in negative $\mathrm{N}$ balance. Their data suggested that clovers must fix upwards of $350 \mathrm{~kg} \mathrm{~N} / \mathrm{ha}$ each year to keep up with $\mathrm{N}$ losses. It seems doubtful that this is achieved, especially during years of poor clover growth, e.g. a cold wet spring. A similar situation probably exists on the more intensively farmed beef farms. This paper reports on a series of trials involving two farmlets, one receiving $\mathrm{N}$ and one not.

\section{TRIAL DESIGN}

Animals were allocated to either a N (-1-N) farmlet or a control no-N (-N) farmlet of 7 ha each year for 4 years. Animals entered the trial in November at 3 months of age $(80 \mathrm{~kg})$. They were grazed through one winter (starting in 1985) and the trial finished each December when slaughter began with the animals at 18 months of age. The animals used were Friesian bulls in 1985, Friesian steers in 1986 and 1987, and Charolais x Angus and Friesian steers in 1988. Stocking rates in the first 3 years were 3.3 animals/ha on the $-\mathrm{N}$ farmlet and 4.3 animals/ha on the $+\mathrm{N}$ farmlet. The objective in these years was to utilise the extra $\mathrm{N}$-boosted grass with the extra animal/ha but not to sacrifice individual animal performance.

The stocking rates in 1988 were kept the same, 3.3. animals/ha, on each farmlet in an endeavour to utilise the extra grass grown in the $+N$ farmlet by way of increased per animal performance.

The results reported here relate to extra pasture grown as a result of $3 \mathrm{~N}$ applications $(50 \mathrm{~kg} \mathrm{~N} / \mathrm{ha})$ in May, July and September. The $+\mathbf{N}$ farmlet did in fact receive an additional dressing (50 kg N/ha) in December. However, decisions made on pattern and rate of animal kill in part to satisfy the needs of work reported elsewhere (Purchas in press), prevent the response to that dressing being reported in the form used here.

The timing of $\mathrm{N}$ application coincided with Ball \& Field's (1982) observations that autumn, late winter/early spring and late spring/early summer were the times that pasture was most responsive to $\mathrm{N}$ fertiliser. The whole area received annual dressings of $125 \mathrm{~kg}$ of superphosphate. The soil type 
of the area was Tokomaru silt loam and the pastures were predominantly ryegrass and white clover.

Grazing management decisions were based on projected pasture growth rates and animal liveweight targets set out for the Tuapaka farm (McRae 1988). If pasture cover declined below $1200 \mathrm{~kg} \mathrm{DM} /$ ha during the slowest pasture growth rate months (June/July) then hay was fed in equal amounts to both treatments.

Pasture cover was monitored using the Ellenbank pasture meter (Earle \& McGowan 1979). Pasture composition was determined at the beginning of the trial (December 1984) and the end of the trial (December 1988). Animals were weighed straight off pasture at strategic intervals. Normal animal health maintenance measures were carried out.

Animal liveweight gains (LMG) were calculated for each farmlet. A statistical comparison of LWG between farmlets requires an estimate of variation in LWG between farmlets. Such an estimate could be obtained by replicating farmlets. The objective of this experiment was to obtain preliminary estimates of the likely benefit of $\mathrm{N}$ fertiliser before dedicating resources to a replicated investigation.

\section{RESULTS}

\section{Liveweight gains}

In 2 of the 3 years $(1985,1987)$, where the $+\mathrm{N}$ farmlet supported a higher stocking rate, LWG did not differ between the treatments (Table 1). In 1986 however, the extra animals/ha carried on the $+\mathbf{N}$ farmlet resulted in lower LWG. In 1988, the animals in the $+\mathrm{N}$ farmlet, stocked at the same rate as those on the $-\mathrm{N}$ farmlet, did not achieve the extra per head performance expected from extra pasture boosted by $\mathrm{N}$ application.

The apparent response to $\mathrm{N}$ within these particular management systems is derived in Table 2. Animal intakes, based on NRC feed tables

Table 1 Effect of treatment on animal liveweight gains and pasture cover.

\begin{tabular}{|c|c|c|c|c|c|c|c|c|}
\hline & \multicolumn{2}{|c|}{1985} & \multicolumn{2}{|c|}{$19 \%$} & \multicolumn{2}{|c|}{1987} & \multicolumn{2}{|c|}{1988} \\
\hline & $+\mathbf{N}$ & $\cdot \mathbf{N}$ & $+\mathrm{N}$ & $-N$ & $+\mathrm{N}$ & $-\mathrm{N}$ & $+\mathbf{N}$ & $-\mathbf{N}$ \\
\hline No. animals & 30 & 23 & 30 & 23 & 30 & 23 & 23 & 23 \\
\hline $\begin{array}{l}\text { stocking rate } \\
\text { (animals ha) }\end{array}$ & 4.3 & 3.3 & 4.3 & 3.3 & 4.3 & 3.3 & 3.3 & 3.3 \\
\hline Sex class & $\mathbf{B}^{\prime}$ & B & S & $\mathbf{s}$ & $S$ & $S$ & $\mathbf{S}$ & $\mathbf{S}$ \\
\hline $\begin{array}{l}\text { Start LW } \\
\text { Finish LW } \\
\text { Days on trial } \\
\text { LW G }\end{array}$ & $\begin{array}{r}267 \\
410 \\
234 \\
0.87\end{array}$ & $\begin{array}{r}211 \\
422 \\
234 \\
0.90\end{array}$ & $\begin{array}{r}193 \\
398 \\
242 \\
0.85\end{array}$ & $\begin{array}{l}202 \\
440 \\
242 \\
0.97\end{array}$ & $\begin{array}{r}182 \\
386 \\
253 \\
0.81\end{array}$ & $\begin{array}{r}187 \\
392 \\
253 \\
0.81\end{array}$ & $\begin{array}{r}197 \\
393 \\
239 \\
0.81\end{array}$ & $\begin{array}{r}205 \\
391 \\
239 \\
0.78\end{array}$ \\
\hline $\begin{array}{l}\text { Pasture cover } \\
\text { Start kg DM/ ha } \\
\text { End kg DM/ ha }\end{array}$ & $\begin{array}{c}1401 \\
1612\end{array}$ & $\begin{array}{r}1332 \\
2282\end{array}$ & $\begin{array}{l}1200 \\
1245\end{array}$ & $\begin{array}{l}1650 \\
1488\end{array}$ & $\begin{array}{l}1412 \\
2010\end{array}$ & $\begin{array}{l}1724 \\
1943\end{array}$ & $\begin{array}{l}2191 \\
2065\end{array}$ & $\begin{array}{l}2276 \\
2013\end{array}$ \\
\hline
\end{tabular}

'B Bull S Steer
(Journeaux 1986) and calculated for the level of performance achieved, were combined with the changes in pasture cover $(\mathrm{kg} \mathrm{DM} / \mathrm{ha})$ over the duration of the trial. The difference in apparent DM production was then expressed as $\mathrm{kg} \mathrm{DM} / \mathrm{kg} \mathrm{N}$ applied. Only in 1987 does this response exceed 10:1.

Table 2 Derived animal intake and pasture responses to $\mathrm{N}$ fertiliser.

\begin{tabular}{|c|c|c|c|c|c|c|c|c|}
\hline & 198 & 85 & & 86 & & 88 & 19 & 888 \\
\hline & $+N$ & $-N$ & $+\mathrm{N}$ & $-\mathrm{N}$ & $+\mathbf{N}$ & $-\mathrm{N}$ & $+\mathbf{N}$ & $-\mathrm{N}$ \\
\hline kg DM intake/anim & al 1555 & 51601 & 154 & 1772 & 1540 & 1578 & 1518 & 1477 \\
\hline $\begin{array}{l}\text { stocking rate } \\
\text { (animals / ha) }\end{array}$ & 4.3 & 3.3 & 4.3 & 3.3 & 4.3 & 3.3 & 3.3 & 3.3 \\
\hline kg DM intake / ha & 6687 & 5283 & 6648 & 5848 & 6622 & 5207 & 5009 & 4874 \\
\hline $\begin{array}{l}\text { q pasture cover } \\
\text { (kg DM / ha) }\end{array}$ & +211 & ,950 & +45 & -162 & +598 & +219 & -126 & -263 \\
\hline kg DM / ha produc & ed 689 & 8623 & 3669 & 35686 & 67220 & 5426 & 4883 & 4611 \\
\hline $\begin{array}{l}\text { Response to N } \\
\text { (kg DM / ha) }\end{array}$ & 665 & & 1007 & & 1794 & & 272 & \\
\hline $\mathrm{kg} \mathrm{DM} / \mathrm{kg} \mathrm{N}$ & 4 & & 7 & & 12 & & 2 & \\
\hline
\end{tabular}

\section{Pasture composition}

The clover content of both farmlets was considerably reduced at the end of the trial, owing to a cold wet and cloudy spring (Table 3 ). However, the decline is as great on the $-\mathrm{N}$ farmlet as on the $+\mathrm{N}$ farmlet.

Table 3 Pasture composition change (December 1984 to December 1988) (\%).

\begin{tabular}{lrrrr}
\hline & \multicolumn{4}{c}{ Treatment } \\
& \multicolumn{3}{c}{ Nitrogen } & - Nitrogen \\
& Start & End & Start & End \\
\hline Grass (leaf + stem) & 59.4 & 68.7 & 56.0 & 72.7 \\
Clover & 28.1 & 19.4 & 32.3 & 15.5 \\
Weed & 11.8 & 5.9 & 10.0 & 4.2 \\
Dead matter & 0.7 & 6.0 & 1.7 & 7.6 \\
\hline
\end{tabular}

\section{Economic value of $\mathrm{N}$ application}

An economic value was assigned to the production achieved on each of the farmlets (Table 4). The carcass weight gain over the period of the trial was valued at $\$ 2 / \mathrm{kg}$, with the production off the $+\mathrm{N}$ farmlet having to meet the costs of the $\mathrm{N}$ fertiliser, and the interest costs associated with an extra animal/ha in the first 3 years.

The extra production covered these costs in only 2 of the 4 years $(1985,1987)$. 
Table 4 Physical and financial responses of $\mathrm{N}$ fertiliser.

\begin{tabular}{lccccccccc}
\hline & \multicolumn{2}{c}{1985} & \multicolumn{2}{c}{1986} & \multicolumn{2}{c}{1987} & \multicolumn{2}{c}{1988} \\
& $+\mathrm{N}$ & $-\mathrm{N}$ & $+\mathrm{N}$ & $-\mathrm{N}$ & $+\mathrm{N}$ & $-\mathrm{N}$ & $+\mathrm{N}$ & $-\mathrm{N}$ \\
\hline $\begin{array}{l}\text { stocking } \\
\text { (animals }\end{array}$ & rate & 4.3 & 3.3 & 4.3 & 3.3 & 4.3 & 3.3 & 3.3 & 3.3
\end{tabular}

Closing LW / ha (kg) 17631393171114521660129412971290

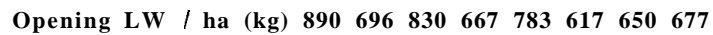

$\begin{array}{lllllllll}\text { LWG/ha (kg) } & 873 & 697 & 881 & 785 & 883 & 677 & 647 & 613\end{array}$

$\begin{array}{lllllllll}\text { GWG' }^{\prime} \text { ha }(\mathrm{kg}) \quad & 436.5 & 348.5 & 440.5 & 392.5 & 441.5 & 338.5 & 323.5 & 306.5\end{array}$

$\begin{array}{lllllllll}\text { Value } \mathrm{CWG}^{2} / \text { ha } & \$ 873 & \$ 697 & \$ 881 & \$ 785 & \$ 883 & \$ 677 & \$ 647 & \$ 613\end{array}$

less

\begin{tabular}{|c|c|c|c|c|}
\hline $\begin{array}{l}\text { Interest on } \\
\text { extra animals }\end{array}$ & $\$ 19$ & $\$ 19$ & $\$ 19$ & $\$ 19$ \\
\hline
\end{tabular}

$\begin{array}{llllllllll}\text { Margin ha } & 6729 & \$ 697 & \$ 727 & \$ 785 & \$ 729 & \$ 677 & \$ 493 & \$ 613\end{array}$

'Carcass weight gain (CWG) is $50 \%$ of liveweight gain (LWG) ${ }^{2} 1 \mathrm{~kg}$ beef $=\$ 2$

${ }^{3} \mathrm{~N}$ fertiliser $=90 \mathrm{c} / \mathrm{kg} \mathrm{N}$ applied

${ }^{4}$ Purchase price of replacements $=\$ 2.00$ head

4 Interest on extra animals charged at $15 \%$ p.a.

\section{Breed comparison}

While the details are not reported in this paper, the LWG of the two breeds (Angus $x$ Charolais, and Friesian) used in the 1988 trial did not differ.

\section{DISCUSSION}

The use of $\mathrm{N}$ fertiliser to fill temporary or projected feed gaps in intensive grazing systems is generally well accepted by the farming community. However, if $\mathrm{N}$ fertiliser is to be used to increase annual pasture production as a profitable means of further increasing the overall profitability of farming systems, then it must be expected to give higher and more consistent responses than those reported in these trials. Only in 1987, where overall a 12:1 response (Table 1) was measured, can the $\mathrm{N}$ applications be seen as profitable.

The $\mathrm{N}$ responses (Table 2) of 7:1 and 2:1 for 1986 and 1988 respectively do not generate enough extra beef to cover the costs of the $\mathrm{N}$ fertiliser (Table 4).

In 1985 the $\mathrm{N}$ response (4: 1) is intermediate to that in these later two years, and the extra production achieved in the $+\mathrm{N}$ farmlet more than covers the extra costs of that system. (\$719/ha for $+\mathrm{N}$ versus $\$ 697 /$ ha for $-\mathrm{N}$ ). However, the pasture cover data (Table 2) for 1985 shows the $-\mathrm{N}$ farmlet finished the trial with a considerable build-up of pasture $(+950 \mathrm{~kg} \mathrm{DM} / \mathrm{ha})$. The extra beef production achieved on the $+\mathrm{N}$ farmlet is therefore due to the extra animals on that treatment harvesting more feed, i.e. a stocking rate effect. However, care must be taken in imputing too much of this result to stocking rate alone. Experience at Tuapaka(McRae 1985) and our observations on other commercial farms suggest that where higher stocking rates have led to feed shortages in late winter, spring growth rates can be reduced. The data reported here do not allow this factor to be investigated further.

The very low response to $\mathrm{N}$ in 1988 , when the stocking rate was held constant on the two farmlets, can probably be explained by climatic conditions in the spring, in particular (cold and water-logged soil), rather than $\mathrm{N}$ limited pasture growth rate.

The apparent lack of effect of $\mathrm{N}$ on pasture composition at a rate of $200 \mathrm{~kg} \mathrm{~N} / \mathrm{ha}^{\mathrm{l}}$ is consistent with the findings of Ball \& Field (1982), who showed that given adequate nutrition and adequate spells between grazing, clover growth need not be affected by $\mathrm{N}$ applications.

\section{CONCLUSIONS}

1. Nitrogen fertilisers at rates up to $200 \mathrm{~kg} \mathrm{~N} /$ ha/yea for 4 years do not appear to reduce the clover content of pastures rotationally grazed by beef animals.

2. Three dressings of $\mathrm{N}$ fertiliser $(50 \mathrm{~kg} \mathrm{~N} / \mathrm{ha})$, in autumn, winter and early spring, do not appear to result in economic increases in pasture production for the beef production system reported here.

3. These findings do not necessarily rule out the use of autumn and winter $\mathrm{N}$ as an economic means of boosting pasture growth rates. This can have two benefits:

(i) preventing late winter pasture cover from falling to critical levels where subsequent regrowth is reduced, and

(ii) allowing more and/or heavier animals to be on hand to better utilise high spring pasture growth rates.

Acknowledgements To the staff of the Sheep and Beef Cattle Unit and other staff at Massey University who assisted with field measurements.

\section{REFERENCES}

Ball, P.R.; Field, T.R.O. 1982. Responses to Nitrogen as Affected by Pasture Characteristics, Season and Grazing Management P 45-65. In Nitrogen Fertilisers in New Zealand Agriculture. P.B. Lynch, New Zealand Institute Agricultural Science.

Earle, D.F.; McGowan, AA. 1979. Evaluation and calibration of an automated rising plate meter for estimating dry matter yield of pasture. Australian Journal of Experimental Agriculture and Animal Husbandry 19: 337-43.

'The effect of 3 dressings $(150 \mathrm{~kg} \mathrm{~N} / \mathrm{ha})$ is reported here, but a further dressing of $50 \mathrm{~kg}$ N/ha was applied each December. 
Field, T.R.O.; Ball, P.R. 1981. Nitrogen balance in an intensively utilised dairy farm system. Proceedings of the NZ G rassland Association 43:64-69.

Hoglund, J.H.; Crush, J.R.; Brock, J.L.; Ball, P.R.; Carran R.A. 1979. Nitrogen fixation in pasture. XII. General discussion. NZ Journal of Experimental Agriculture $7: 45-51$.

Journeaux, P. 1986. Bull Beef Production Systems for Wairarapa hill country. Unpublished MAgrSci Thesis. Massey University.
McRae, A.F. 1985. Tuapaka Beef Unit (The First Two Seasons). Tuapaka Farm Publication No. 2. Massey University. p24.

McRae, A.F. 1988. Bull Beef Production: The Tuapaka Experience. Proceedings of the NZ Grassland Association 49:41-45 pl1-17.

Syers, J.K. 1982. Introduction. In Nitrogen fertilisers in New Zealand Agriculture. Edit. P.B. Lynch. New Zealand Agricultural Science. 